\title{
CERTIORARI AND THE CORRECTION OF INTRA-JURISDICTIONAL ERRORS OF LAW
}

\author{
D. P. JONES* AND ANNE de VILLARS**
}

\section{INTRODUCTION}

The purpose of this paper is to examine the anomalous use of certiorari to correct certain intra-jurisdictional errors of law on the face of the record of proceedings taken by a statutory delegate. This requires consideration of: (1) the distinction between errors which deprive a statutory delegate of his jurisdiction, and errors which are not jurisdictional in nature; (2) the general limitations on certiorari as a remedy; (3) the extent of the "record"; (4) the distinction between an error of "law" and other kinds of errors; (5) the use of the "patently unreasonable" test to avoid the effect of a privative clause; and (6) the new use of the "patently unreasonable" test upon the exercise of the court's discretion to refuse a prerogative remedy, particularly when there is no privative clause to protect an intra-jurisdictional error of law. Finally, reference will be made to the similar (but separate) common law power of the superior courts to quash and remit the decision of a consensual arbitrator who has committed an error of law.

\section{THE DISTINCTION BETWEEN JURISDICTIONAL AND NON-JURISDICTIONAL ERRORS OF LAW}

Although almost all grounds for judicial review concentrate on the jurisdiction of a statutory delegate, certiorari is also sometimes available to correct errors of law made by the delegate within his jurisdiction. This anomaly was referred to by Lord Sumner in $R$. v. Nat Bell Liquors Limited, ${ }^{1}$ and resuscitated by Denning L.J. in Rex v. Northumberland Compensation Appeal Tribunal, ex parte Shaw. ${ }^{2}$ In theory, this use of certiorari permits the court to make sure that all statutory delegates abide by the law of the land. This ground of judicial review is subject to restriction by the enactment of a privative clauses, and is also subject to the court's inherent discretion to refuse prerogative remedies. Both of these restrictions seriously complicate this area of the law and they will be considered in detail below. Further, it is often extremely difficult to determine whether an error deprives the delegate of his jurisdiction or lies within it.

No satisfactory test has ever been developed for distinguishing between jurisdiction and non-jurisdictional errors. Nevertheless, the distinction between these two concepts is important for at least five reasons. First, a privative clause cannot effectively prevent judicial review where the jurisdiction of the delegate is in question, but will be effective to prevent the superior courts from using certiorari to correct mere errors of law on the face of the record. Secondly, affidavits and other evidence are ad-

- Of the Faculty of Law at The University of Alberta, Edmonton.

** Of McCuaig, Desrochers, Barristers \& Solicitors, Edmonton.

*** Based on a portion of the authors' forthcoming text on administrative law, to be published by Carswell.

1. [1922] 2 A.C. 128 (P.C.).

2. [1952]1 K.B. 338 (C.A.), on appeal from [1951] 1 K.B. 711. 
missible if necessary to prove the existence of a jurisdictional error, but they cannot be considered by the court if a non-jurisdictional error of law is involved. Thirdly, the court's anomalous power to correct intrajurisdictional errors is limited to errors of law only, and does not apply to errors of fact; whereas factual matters may give rise to a jurisdictional error, particularly in the context of the preliminary or collateral fact doctrine. Fourthly, this anomalous use of certiorari can only correct errors of law which appear on the face of the record, however that is defined; whereas jurisdictional errors do not have to be so disclosed. Finally, it may not be possible to correct intra-jurisdictional errors by any remedy other than this anomalous use of certiorari, ${ }^{3}$ although other remedies may frequently be available to review jurisdictional errors.

\section{INHERENT LIMITATIONS ON THE AVAILABILITY OF CERTIORARI AS A REMEDY TO CORRECT ERRORS OF LAW}

Because errors of law on the face of the record can sometimes be corrected by certiorari, this ground for judicial review will generally only be available to the extent to which certiorari is available as a remedy.

\section{A. THE AMBIT OF CERTIORARI AGAINST ADMINISTRATIVE DECISIONS}

Formerly, it was thought that certiorari was only available against judicial or quasi-judicial bodies, and not against merely administrative ones. However, at least since the Nicholson ${ }^{4}$ and Martineau (No. 2) ${ }^{5}$ cases, the ambit of certiorari has been expanded to supervise the procedural fairness of merely administrative bodies. In principle, therefore, certiorari should be available to correct errors of law committed by merely administrative bodies, and not be restricted to those which are exercising judicial or quasi-judicial functions.

\section{B. IS A STATUTORY DELEGATE INVOLVED?}

Certiorari is also only available against the exercise of a statutory power. Thus, in Re Minister of Education and Civil Service Association (Alberta), ${ }^{6}$ the Court of Appeal held that certiorari was not available to supervise the exercise of judicial powers created by an agreement. The same difficulty has long plagued attempts to obtain certiorari against labour arbitration boards. On the one hand, some labour arbitration boards are established by statute, and certiorari will ${ }^{7}$ be available to cor-

3. E.g., by a declaration, which will not quash the delegate's decision. See Punton v. Ministry of Pensions and National Insurance (No. 2) [1964]1 W.L.R. 226 (C.A.).

4. (1978) 88 D.L.R. (3d) 671 (S.C.C.).

5. [1980]1 S.C.R. 602 .

6. (1976) 70 D.L.R. (3d) 696 at 699, 2 A.R. 43. (Alta. S.C. App. Div.) See also the reasoning of Clement J.A. in the Inland Cement case [1981] 3 W.W.R. 65 (Alta. C.A.) to the effect that arbitration boards constituted under the 1980 Alberta Labour Relations Act are indeed statutory, following the Rivando case from Ontario. In 1977 the words "or otherwise" were removed from the Alberta Labour Act, thereby really putting the statutory nature of labour arbitration boards beyond question in this province. This realization would have pre-empted a considerable part of the subsequent judgment by Kerans J.A. in Suncor, discussed below.

7. In the absence of an ef fective privative clause. 
rect at least some errors of law made on the face of their records. On the other hand, other labour legislation merely provides the vehicle through which collective agreements are reached, including a statutory obligation to include an arbitration clause in such agreements. The courts have vacillated about the availability of certiorari to correct errors of law committed by such consensual arbitration boards. This point appears to have been recently settled affirmatively by the Supreme Court of Canada in Roberval Express Ltd. v. Transport Drivers, Warehousemen and General Workers' Union, Local 106. ${ }^{8}$ This decision will in effect convert many labour arbitrations into statutory proceedings, thereby bringing them within the ambit of certiorari. Nevertheless, certiorari is still not available against non-statutory decisions, and it is important to remember the existence of the separate common law remedy to quash and remit a consensual arbitrator's decision for misconduct (discussed in Part 8 below).

\section{THE RECORD}

\section{What, then, constitutes the record? Lord Denning said this in the Shaw case: ${ }^{9}$}

It has been said to consist of all those documents which are kept by the tribunal for a permanent memorial and testimony of their proceedings: see Blackstone's Commentaries, Vol. III, at p. 24. But it must be noted that, whenever there was any question as to what should, or should not be, included in the record of any tribunal, the Court of King's Bench used to determine it. It did it in this way: When the tribunal sent their record to the King's Bench in answer to the writ of certiorari, this return was examined, and if it was defective or incomplete it was quashed: see Apsley's case, ${ }^{10}$ Rex v. Levermore, 11 and Ashley's case, ${ }^{12}$ or, alternatively, the tribunal might be ordered to complete it: Williams v. Bagot ${ }^{13}$ and Rex v. Warnford. ${ }^{14}$ It appears that the Court of King's Bench always insisted that the record should contain, or recite, the document or information which initiated the proceedings and thus gave the tribunal its jurisdiction; and also the document which contained their adjudication. Thus in the old days the record sent up by the justices had, in the case of a conviction, to recite the information in its precise terms; and in the case of an order which had been decided by quarter sessions by way of appeal, the record had to set out the order appealed from: see Anon. ${ }^{15}$ The record had also to set out the adjudication, but it was never necessary to set out the reasons (see South Cadbury (Inhabitants) v. Braddon, Somerset (Inhabitants ${ }^{18}$ ) nor the evidence, save in the case of convictions. Following these cases, I think the record must

8. [1982] 2 S.C.R. 888,83 C.L.L.C. page 12102 at para. 14023 , reversing its previous decision in Howe Sound Company and International Union of Mine, Mill and Smelter Workers (Canada) Local 663 [1962] S.C.R. 318, 62 C.L.L.C. para. 15407A, which held that there could only be a statutory arbitrator if the parties were compelled by statute to submit their disputes to that person, and did not have the option of settling those disputes by some other method. Such compulsion was the case in Port Arthur Ship Building Company and Harry W. Arthurs [1969] S.C.R. 85, 68 C.L.L.C. para. 14136; and Re the International Nickel Company of Canada Limited and Rivando 56 C.L.L.C. para. 15263, [1956] O.R. 379.

9. [1952] 1 K.B. 338 at p. 352, [1952] 1 All E.R. 122 (C.A. Eng.); footnotes re-numbered. See also the decision in Baldwin \& Francis Ltd. v. Patent Appeal Tribunal [1959] A.C. 663 (H.L.), [1959] 2 W.L.R. 826, [1959] 2 All E.R. 433 at 445; Stedelbauer Chevrolet Oldsmobile Ltd. v. Industrial Relations Board (Alta.) [1969] S.C.R. 137, 1 D.L.R. (3d) 81; affg. (1967) 61 D.L.R. (2d) 401, 59 W.W.R. 269 at 278.

10. (1671) Sty. 85 .

11. (1701) 1 Salk. 146.

12. (1698) 2 Salk. 479.

13. 4 Dow. \& Ry. K.B. 315.

14. (1825) 5 Dow. \& Ry. K.B. 489.

15. (1697) 2 Salk. 479.

16. (1710) 2 Salk. 607. 
contain at least the document which initiates the proceedings; the pleadings, if any; and the adjudication; but not the evidence, nor the reasons, unless the tribunal chooses to incorporate them. If the tribunal does state its reasons, and those reasons are wrong in law, certiorari lies to quash the decision.

A nice question arises whether the record includes the evidence presented to a statutory delegate during the course of his proceedings. On the one hand, the decision in Farrell v. Workmen's Compensation Bd. ${ }^{17}$ specifically holds that the record consists only of the initiating document, the pleadings (if any), and the adjudication (including the reasons if incorporated therein), but not the evidence or the supporting documents referred to in the decision. In Alberta, the Rules of Court ${ }^{18}$ effectively deem the following documents to be part of the record which the decision-maker is required to return to the Court of Queen's Bench in an application for certiorari; the judgment, order or decision (as the case may be) and reasons therefore, together with the process commencing the proceedings, the evidence and all exhibits filed (if any), and all things touching the matter, together with the notice of motion for certiorari. Accordingly, it appears that the definition of the record has been extended in Alberta to include all of the evidence. ${ }^{19}$ To this extent, therefore, it may be possible to use the extended record in Alberta to demonstrate errors of law which can be corrected by the anomalous use of certiorari. On the other hand, administrative bodies often do not make verbatim transcripts or tape recordings of their proceedings, and are generally under no duty to do so. ${ }^{19}$ As a result, it may not be possible to show an error of law on the face of even the extended record: the delegate's decision may still be "the inscrutable face of the sphinx" 20 immune from judicial review.

Secondly, a similar problem relates to whether notes taken by a statutory delegate form part of the record. These notes are not themselves evidence, but may be summaries of the evidence. In Walkerv. Keating, ${ }^{21}$ the Appeal Division of the Nova Scotia Supreme Court declined to include the hand-written notes of the chairman of a three-member tribunal as part of the record. By contrast, the Trial Division of that same court did order the notes of a sole arbitrator to be included in the record in Construction Association Management Labour Bureau Ltd. v. International Brotherhood of Electrical Workers, Local 625, ${ }^{22}$ apparent-

17. [1962] S.C.R. 48, 31 D.L.R. (2d) 177, 37 W.W.R. 39; affg. (1961) 26 D.L.R. (2d) 185, 33 W.W.R. 433 (B.C.C.A.).

18. Rule 743 in civil matters, Rule 831 in criminal matters.

19. Note: In Woodward Stores [1976] 5 W.W.R. 496 (Alta. S.C.), D.C. McDonald J. queried whether such an extension to the record could be accomplished by Rule of Court, in light of the fact that such an extension might af fect the substantive law which could not be changed by rule. This possible problem no longer exists because s. 47(2) of the Judicature Act, R.S.A. 1980, c. J-1 validates the Rules of Court notwithstanding that any provision therein may affect substantive rights.

19a. If proceedings are tape recorded, the practice in Alberta appears to be to include the tape as part of the record returned to the court. However, the court has held that no jurisdictional error arises where the tape is unintelligible: see the Canron case (1983) 43 A.R. 299 (Alta. Q.B.).

20. R. v. Nat Bell Liquors Ltd. [1922] A.C. 128 (P.C.), 65 D.L.R. 1 per Lord Sumner at p. 25.

21. (1973) 6 N.S.R. (2d) 1 (N.S.S.C. App. Div.).

22. (1983) 34 C.P.C. 65 (N.S.S.C.T.D.). 
ly because there could be no possibility of a difference in the notes taken by the various members of the tribunal. On the other hand, this last case holds that copies of decisions and other authorities submitted to the tribunal do not form part of its record, even though they are "other papers or documents in the proceeding" 23 and "touch the matter" 24 being questioned by certiorari. Oddly, the dissenting decision of a multimember statutory body has been held not to constitute part of the record. ${ }^{25}$ In principle, correspondence between members of a statutory body, written after the hearing for the purpose of discussing the issues, should not form part of the record, because it does not effect the proceedings at the hearing. If such documents exist, the person making the Return to the court cannot sign the certificate as drafted in Rule $744,{ }^{26}$ and should probably alter the certificate to reflect that certain documents in his possession are not properly returnable to the court as part of the record. At least such a procedure discloses the existence of such materials, and leaves it open to the judge to determine whether they are part of the record.

23. N.S. rule.

24. Alberta rule.

25. City of Regina v. Amalgamated Transit Union Division No. 58867 D.L.R. (3d) 533, [1976] 3 W.W.R. 687 (S.C.A.); affg. 61 D.L.R. (3d) 376, [1976] 1 W.W.R. 334 (S.Q.B.). However, Counsel often puts the dissenting reasons before the court by affidavit. For a different view, see Milan and United Steelworkers of America, Local Union 804 v. Cominco Limited (unreported; S.C.N.W.T. per Morrow J., 28 Nov. 1972).

26. Rule 744 provides as follows:

744(1) Upon receiving the notice so endorsed the justice or justices, officer, clerk or tribunal shall return forthwith to the of fice mentioned therein the judgment, order, warrant or decision together with the process commencing the proceedings, the evidence and all exhibits filed, if any, and all things touching the matter and the notice served upon him with a certificate endorsed thereon in the following form:

"Pursuant to the accompanying notice I herewith return to the Honourable Court the following papers and documents, that is to say-

(a) the judgment, order, decision (or as the case may be) and the reasons therefor;

(b) the process commencing the proceedings and the warrant issued thereon;

(c) the evidence taken at the hearing and all exhibits filed;

(d) all other papers or documents touching the matter.

"And $I$ hereby certify to this Honourable Court that I have above truly set forth all the papers and douments in my custody and power relating to the matter set forth in the notice of motion."

(2) If the proceedings are not in the possession of the person required to transmit them, he shall in lieu of the certificate, so state and explain the circumstances.

(3) If the proceedings have not been received by the of ficer to whom or the clerk of the of fice to which they are by law required to be transmitted, that of ficer or clerk shall return a certificate of the fact.

(4) The certificate prescribed in subrule (1) or (2) has the same effect as a return to a writ of certiorari.

(5) The court may dispense with the return of the evidence or exhibits or part of them.

(6) A copy of this Rule shall appear upon or be annexed to the notice of motion served upon the provincial judge, justice or justices, clerk or officer or tribunal from whom the return is required: 
Finally, it is sometimes possible to extend the record by agreement. As Lord Denning noted in the Shaw case: ${ }^{27}$

\begin{abstract}
Notwithstanding the strictness of the rule that the error of law must appear on the face of the record, the parties could always by agreement overcome this difficulty. If they both desired a ruling of the court of King's Bench on a point of law which had been decided by the tribunal, but which had not been entered on the record, the parties could agree that the question should be argued and determined as if it were expressed in the order. The first case I have found in which this was done was in $1792, \operatorname{Rex} v$. Essex, ${ }^{28}$ but thereafter it was quite common. It became a regular practice for parties to supplement the record by affidavits disclosing the points of law that had been decided by the tribunal. This course was only taken if no one objected. It seems to have been adopted by litigants as a convenient alternative to asking the tribunal to make a speaking order. Thus, in the numerous cases on the validity of a sewer's rate, it was the regular course of proceeding for affidavits to be lodged stating the objections in law to the rate; and the case was decided on the objections stated in the affidavits: see, for instance, Rex v. Tower Hamlets. ${ }^{29}$ Recent cases such as Rex v. West Riding of Yorkshire Justices ${ }^{30}$ and General Medical Council v. Spackman ${ }^{31}$ show that the practice continues today. The explanation of all these cases is, I think, that the affidavits are treated by consent as if they were part of the record and make it into a speaking order.
\end{abstract}

\title{
V. ERRORS OF LAW VERSUS ERRORS OF FACT
}

As its name implies, the anomalous use of certiorari to quash errors of law on the face of the record requires there to be an error of law, and not some other type of mistake. Thus, certiorari will not issue to correct an error of fact. ${ }^{32}$ Nevertheless, what constitutes an "error of law" is to be widely construed, and probably has a meaning similar to the phrase used for determining the right of appeal on a point of law. Wade ${ }^{33}$ describes the distinction as follows:

There is only one clear and logical point at which the line [between errors of law and errors of fact] can be drawn, and it has been recognized in many judgments. This is that questions of fact are the primary facts of the particular case which have to be established before the law can be applied, the "facts which are observed by the witnesses and proven by testimony", to which should be added any facts of common knowledge of which the court will take notice without proof. Whether these facts, once established, satisfy some legal definition or requirement is a question of law, for the question then is how to interpret and apply the law to those established facts. If the question is whether some building is a "house" within the meaning of the Housing Acts, its location, condition, purpose of use and so forth are questions of fact. But once these facts are established, the question whether it counts as a house within the meaning of the Act is a question of law ....

In principle, therefore, an appeal on a point of law should be available on every question of legal interpretation arising after the primary facts have been established. It ought to cover all legal "inferences from facts", as they are often called. It should cover all questions of causation. But the courts have laid down a narrower doctrine, designed to give greater latitude to tribunals where there is a difference of opinion. The rule is that the application of a legal definition or principle to ascertain the facts is erroneous in point of law only if the conclusion reached by the tribunal is unreasonable. If it is within the range of interpretations within which different persons might reasonably reach different conclusions, the court will hold there is no error of law.

27. Supran. 9 at p. 353.

28. (1792) 4 T.R. 591.

29. (1829) 9 B. \& C. 517.

30. [1910] 2 K.B. 192.

31. [1943] A.C. 627; affg.; [1942] 2 K.B. 261.

32. See R. v. Criminal Injuries Compensation Board, ex parte Staten [1972] 1 W.L.R. 569. (Eng. Q.B.).

33. H.W.R. Wade, Administrative Law (4th ed. 1977) 775. 
The "unreasonableness" doctrine for defining errors of law is considered in detail in Parts 6 and 7 of this paper.

It would be wrong, however, to assume that errors of fact made by an administrative tribunal can never be the subject of judicial review, although such review clearly would relate to jurisdiction. To the extent that a statutory delegate has discretion to determine the facts, he must exercise his discretion reasonably. If he does so, he is acting within his jurisdiction, and no judicial review can arise (because there is no jurisdictional error, and there is no error of law within jurisdiction). On the other hand, if the statutory delegate exercises his discretion to determine the facts in an unreasonable manner, he has not in law exercised his discretion, but rather has declined jurisdiction. The normal grounds for reviewing a jurisdictional error, therefore, should in principle be available in such a circumstance. This situation sometimes arises in determining whether to review the decision of a statutory delegate on the basis that there was no or insufficient evidence before him to support his finding. The courts appear to have adopted the view in Nat Bell Liquors ${ }^{34}$ that the sufficiency of evidence is not a question of law, and therefore an erroneous appraisal of the evidence by a statutory delegate will not give rise to the anomalous use of certiorari to correct an error of law on the face of the record. On the other hand, total lack of evidence appears to be a jurisdictional error capable of judicial review, even in the face of a privative clause. Similarly, it is submitted that an unreasonable appreciation of the facts may constitute a jurisdictional defect in the tribunal's proceedings.

\section{THE "PATENTLY UNREASONABLE" DOCTRINE IN THE FACE OF A PRIVATIVE CLAUSE}

Errors of law on the face of the record cannot be corrected by the anomalous use of certiorari if there is a statutory ${ }^{35}$ privative clause preventing judicial review of errors made within a delegate's jurisdiction. Of course privative clauses ${ }^{36}$ cannot constitutionally be effective to oust judicial review of jurisdictional questions, on the rationale that a statutory delegate cannot lawfully make a decision outside his jurisdiction, so there is nothing to be protected by the privative clause. Precisely because intra-jurisdictional errors of law lie within the delegate's jurisdiction, however, means that there is a decision or action which can be protected by the privative clause. In order to succeed in obtaining judicial

34. Supra n. 20. See also D.W. Elliott's excellent article entitled "No Evidence - A Ground for Judicial Review in Canada?" (1972-73) 37 Sask. L.R.48.

35. I.e., in the same statute as creates the delegate's power to do the act in question. There may be some doubt as to the precise meaning of a privative clause, particularly (as in the Olds College, UNA and Suncor cases discussed below) where the Act specifically provides that certiorari or some other remedy is available in some short period of time (e.g., 30 days). Does a "no certiorari" clause have the same effect as a "final and binding" clause? These are difficult questions of statutory construction. See S. Chumir, "The Rammell and Farrell Cases" (1963) 3 Alta. L.R. 124 for a discussion of different types of privative clauses. See also Pringle v. Fraser (1972) 26 D.L.R. (3d) 28 (S.C.C.); Re Woodward Estate (1972) 27 D.L.R. (3d) 608 (S.C.C.); and Toronto Newspaper Guild v. Globe Printing Co. [1953] 3 D.L.R. 561 (S.C.C.).

36. Loosely defined, to include all of those types referred to in $\mathrm{n}$. 35 , supra. 
review when there is a privative clause, therefore, one must show that a jurisdictional error has been committed by the delegate. A vast number of cases can be used to illustrate attempts to characterize particular errors of law as "going to jurisdiction". Until recently, it was probably true to state that no satisfactory test had ever been devised to differentiate intrajurisdictional errors of law from those which go to jurisdiction.

A line of recent cases has recently developed the doctrine that errors of law which are "patently unreasonable" are jurisdictional in nature, and therefore cannot be immunized from judicial review by a privative clause. This is not new law, but has been restated by Dickson J. in Canadian Union of Public Employees, Local 963 v. New Brunswick Liquor Corporation. ${ }^{37}$ Because the rhetoric of this decision has been extended into other circumstances, where it is arguably inappropriate, it is important to examine the CUPE and subsequent cases in some detail.

\section{A. THE CUPE CASE}

The CUPE case dealt with a complaint by a Union that the New Brunswick Liquor Corporation was replacing striking employees with management personnel contrary to s. 102(3)(a) of the Public Service Labour Relations Act, ${ }^{38}$ which provided as follows:

102(3) Where subsection (1) and subsection (2) are complied with employees may strike and during the continuance of a strike

(a) the Employer shall not replace the striking employees or fill their position with any other employee, and

(b) no employee shall picket, parade or in any manner demonstrate in or near any place of business of the employer.

The question arose as to whether the use of management personnel to perform the functions of striking workers constituted an illegal "replacement" within the meaning of section 102(3)(a). The Board ruled that it did, and was illegal. However, a majority of the Court of Appeal disagreed with the Board's legal interpretation of this section, and went on to hold that this question was preliminary or collateral to the Board's jurisdiction under the Act. Accordingly, the Court of Appeal held that there was only one correct interpretation of the section, and it was for the Court (or a majority of it) to determine what that correct interpretation was.

The Supreme Court of Canada characterized the matter somewhat differently. In the first place, Dickson J. held that the correct interpretation of s. 102(3)(a) was not preliminary or collateral to the Board's jurisdiction, which must be determined at the outset of the inquiry. ${ }^{39}$ In Dickson J.'s words: ${ }^{40}$

The question of what is and is not jurisdictional is often very difficult to determine. The Courts, in my view, should not be alert to brand as jurisdictional, and therefore subject to broader curial review, that which may be doubtfully so.

37. (1979) 97 D.L.R. (3d) 417 (S.C.C.).

38. R.S.N.B. 1973, c. P-25.

39. Supra n. 37 at 421 and 422 .

40. Id. at p. 422 . 
His Lordship noted that the general subject matter of the dispute between the parties unquestionably fell within the confines of the legislation, and the Board was asked by the parties to determine whether certain activities of the Union and of the Employer during the lawful strike were in violation of the prohibition contained in the provision in question. Accordingly, it was not possible to suggest that the Board did not have "jurisdiction in the narrow sense of authority to enter upon an inquiry". ${ }^{41}$ Accordingly, the Supreme Court rejected the relevance of the Jacmain ${ }^{42}$ Parkhill Bedding, ${ }^{43}$ and Jarvis ${ }^{44}$ cases, in all of which, at the threshold of the inquiry, the statutory delegate had to determine whether the case before them was one of the kind upon which the empowering statute permitted entering an inquiry.

Dickson J. then noted that s. 101 of the Act contained the following privative clause:

101(1) Except as provided in this Act, every order, award, direction, decision, declaration or ruling of the Board, the Arbitration Tribunal or an adjudicator is final and shall not be questioned or reviewed in any court.

(2) No order shall be made or process entered, and no proceeding shall be taken in any court, whether by way of injunction, certiorari, prohibition, quo warranto, or otherwise, to question, review, prohibit or restrain the Board, the Arbitration Tribunal or an adjudicator in any of its or his proceedings.

His Lordship referred to the policy reasons for including such a privative clause to protect a Labour Board's decision within jurisdiction, on the basis that it is a specialized ${ }^{45}$ tribunal administering a comprehensive statute regulating difficult labour relations. He also noted ${ }^{46}$ the reasons why the superior courts have tended to exercise their discretion to refuse prerogative remedies against such specialized statutory delegates dealing with labour relations. Accordingly, the ratio decidendi of the Supreme Court's decision in CUPE is that the legal error, if any, committed by the Board lay within its jurisdiction, and was not "patently unreasonable" 47 but was at least as reasonable as the numerous alternative interpretations suggested in the Court of Appeal. In the end, the Board could not be said to have so misinterpreted the statutory provision as to "embark on an inquiry or answer a question not remitted to it".

One can summarize the reasoning in the CUPE decision as follows. On the one hand, it is frequently very difficult to determine which errors are jurisdictional in nature, and which lie within the jurisdiction of a statutory delegate. The "jurisdiction" of a statutory delegate is generally to be determined in the narrow sense of authority to enter upon an inquiry, although it includes doing something subsequently to take the

41. See Service Employees' International Union, Local No. 333 v. Nipawin District Staff Nurses' Association of Nipawin (1975) I S.C.R. 382 at p. 389, (1973) 41 D.L.R. (3d) 6 at p. 11, [1974] 1 W.W.R. 653 .

42. [1978] 2 S.C.R. 15, (1977) 81 D.L.R. (3d) 1, 18 N.R. 361.

43. (1961) 26 D.L.R.(2d) 589, 34 W.W.R. 13 (Man. C.A.).

44. (1964) 44 D.L.R. (2d) 407, [1964] S.C.R. 497.

45. The courts have used other rationales for deferring to statutory delegates' decisions. See Part 10 of this paper, infra.

46. Supran. 37 at 424.

47. Supra n. 37 at 429. 
statutory delegate outside the ambit of its powers (and therefore outside the protective ambit of a privative or preclusive clause) such as:48

\footnotetext{
... acting in bad faith, basing the decision on extraneous matters, failing to take relevant factors into account, breaching the provisions of natural justice or misinterpreting provisions of the Act so as to embark on an inquiry or answer a question not remitted to it.
}

As long as the legislative provisions are not preliminary or collateral in nature (however that characterization is determined), the CUPE decision seems to hold that only a patently unreasonable interpretation of the statutory provisions in question will make an arguably incorrect legal interpretation into a jurisdictional error, which therefore would not be protected by a privative clause. Thus, the "patently unreasonable" test is used to determine which legal errors within jurisdiction are so serious as to cause a delegate who has jurisdiction in the narrow sense to exceed or depart from his jurisdiction. "Patently unreasonable" is therefore a test for determining which errors are jurisdictional in nature. The effect of a successful application of the "patently unreasonable" doctrine is to evade the operation of a privative clause; that is, to use "patently unreasonable" as a sword for judicial review of administrative action. Conversely errors of law which are not "patently unreasonable", and which do not relate to a matter which is preliminary or collateral to the delegate's jurisdiction in the narrow sense, are intra-jurisdictional in nature and will be immunized from judicial review whenever there is a privative clause. This is the result of the doctrine of parliamentary sovereignty, under which the legislative branch may specifically exclude judicial review.

\section{B. THE MASSICOTTE CASE}

A similar result was reached by the Supreme Court of Canada in Teamsters' Union, Local 938 v. Massicotte. ${ }^{49}$ This case dealt with whether the Canada Labour Relations Board had exceeded or left its jurisdiction after it had found that a union had violated its duty of fair representation in failing to permit a part-time employee to grieve his dismissal, and ordered arbitration of the grievance. Subsection 122(2) of the Canada Labour Code ${ }^{50}$ contains a very strong privative clause, which goes so far as to prevent judicial review:

\footnotetext{
... on any ground, including the ground that the order, decision or proceeding is beyond the jurisdiction of the Board to make or carry on or that, in the course of any proceeding, the Board for any reason exceeded or lost its jurisdiction.
}

Subsection 122(1) of the Code does provide a narrow range for judicial review by the Federal Court of Appeal pursuant to paragraph 28(1)(a) of the Federal Court Act, ${ }^{51}$ which is restricted to two grounds only: namely, failure to observe a principle of natural justice, or otherwise acting beyond or refusing to exercise jurisdiction.

48. Supra n. 41 at pp. 11-12 (D.L.R.) and 389 (S.C.R.).

49. (1982) 134 D.L.R. (3d) 385 (S.C.C.).

50. R.S.C. 1970 , c. L-1, as amended by S.C. 1972, c. 18, s. 1, and by S.C. 1977-78, c. 27 , s. 43.

51. R.S.C. 1970 , c. 10 (2nd Supp.). 
Again, the appellant union tried to characterize the issue as one of a matter that was preliminary or collateral to the Board's jurisdiction. ${ }^{52}$ The union submitted that a jurisdictional error was involved because of the Board's alleged patent unreasonableness in interpreting its powers to order the arbitration at the instance of the member of the union, when the union itself had not chosen to go to arbitration.

Chief Justice Laskin, writing for a unanimous five-member ${ }^{53}$ panel of the Supreme Court of Canada, clearly rejected the notion that any preliminary or collateral matter was involved in this case. As the Chief Justice said, ${ }^{54}$ there could be no question of the authority of the Canada Labour Relations Board to deal with the complaint of Massicotte as a part-time employee. His Lordship seems to indicate that an intrajurisdictional question arises in the following circumstances: ${ }^{55}$

I do not see . . . any basis for questioning the jurisdiction exercised in the present case by the Canada Labour Relations Board. Essentially, this Court has admonished that there must be no failure of natural justice (and there was none here) and that the Board should address itself to an issue arising under the legislation which it is charged to administer. If it has done this (as the Federal Court of Appeal held and, in my opinion, rightly so) there can be no jurisdictional infirmaty when the Board is protected in its determinations by a privative clause. It may be wrong in law in interpreting the range of powers confided to it but its decisions are none of the less immunized from judicial review.

Further, His Lordship went on:56

... [M]ere doubt as to correctness of a labour board interpretation of its statutory power is no ground for finding jurisdictional error, especially when the labour board is exercising powers confided to it in wide terms to resolve competing contentions. Insofar as the Anisminic and Metropolitan Life Insurance cases deal with the so-called "wrong question" test of jurisdiction, they have no relevance here. It is impossible to say that the Canada Labour Relations Board asked itself the wrong question in any sense of departing from the inquiry in which it was engaged. It addressed itself to the issue raised by the complaint and exercised powers in relation thereto which it clearly had. At bottom, the objection is to the consequential results of that exercise, but this is a long way from any jurisdictional issue.

In the result, I am of the opinion that there is no question of jurisdiction involved in the objection to what the Canada Labour Relations Board did. Its decision and remedial order are hence not reviewable and this appeal therefore fails . . . .

Massicotte, therefore, exactly follows the rule set down in CUPE.

\section{THE VOLVO CASE}

Strictly speaking, the reasoning of the Supreme Court of Canada in Volvo Canada Ltd. v. International Union, United Automobile, Aerospace and Agricultural Implement Workers of America, Local $720,{ }^{57}$ does not apply to the test for reviewing errors of law made by a statutory delegate, but rather deals with the grounds for review of a consensual arbitrator. As a result, the case deals with an important side issue

52. Relying on the Nipawin, Jacmain, CUPE, Anisminic, and Metropolitan Life Insurance cases.

53. Composed of Laskin C.J.C. and Dickson, Beetz, Chouinard and Lamer JJ.

54. Supra n. 49 at 390.

55. Supra n. 49 at 391 .

56. Supra n. 49 at 395.

57. (1979) 99 D.L.R. (3d) 193 (S.C.C.). 
of whether a "specific question of law" had been remitted to the consensual arbitrator for determination (in which case judicial review by the common law action to quash and remit is not available, even if the arbitrator has given clauses of the collective agreement an interpretation which their language will not reasonably bear), or whether the submission to arbitration was a "general question" in the determination of which a question of law incidentally arose (in which case judicial review would be available, but only if the arbitrator's interpretation was one which the collective agreement could not reasonably bear). In the result, all nine members of the Supreme Court of Canada declined to interfere with the arbitrator's decision, although for different reasons. ${ }^{58}$ The Court has returned to this issue in the Shalansky decision, which dealt with a consensual arbitration of a general (and not specific) question of construction of a collective agreement. ${ }^{59}$

\section{UNITED NURSES OF ALBERTA, LOCAL 11 AND THOMAS V. MISERICORDIA HOSPITAL}

The "patently unreasonable" test has also been adopted by the Alberta Court of Appeal in the U.N.A. case. ${ }^{60}$ The issue dealt with was whether the Arbitration Board had correctly dismissed a grievance on the basis that the employer had reserved the right to dismiss employees without cause under the terms of the collective agreement, and as such the issue was not arbitrable. The Court of Appeal unanimously held that the question of whether an issue was arbitrable was clearly within the jurisdiction of the Board of Arbitration pursuant to the very specific wording of section 138 of the Alberta Labour Act, ${ }^{61}$ which provides as follows:

138 Every collective agreement must contain a method for the settlement of differences arising

(a) as to the interpretation, application or operation of a collective agreement,

(b) with respect to a contravention or alleged contravention of a collective agreement, and

(c) as to whether a difference referred to in clause (a) or (b) can be the subject of arbitration

between the parties to or parties bound by the collective agreement.

58. On the one hand, three members of the court (Laskin, C.J.C., Spence and Dickson, JJ.) held that a specific question of law had been referred to the arbitrator and could not be reviewed by the courts in any way. On the other hand, five members of the Court (Martland, Ritchie, Pigeon, Beetz and Pratte, JJ.) declined to hold that a specific question of law had been remitted to the arbitrator, but nevertheless refused to interfere with the arbitrator's award because it was not unreasonable. Estey $\mathrm{J}$. was in favour of rejecting the distinction between a general question and a specific question of law, but would have limited judicial review to those cases where the arbitrator, in answering the question remitted to him, does something he is not by statute or contract authorized to do.

59. A unanimous five member panel of the Supreme Court of Canada held that the common law action to remit and quash a consensual arbitrator's decision - at least on a general question - can only arise if it involves an interpretation which the word of a collective agreement could not reasonably bear. See Part 8 of this paper, infra.

60. [1983] 6 W.W.R. 1 (Alta. C.A.).

61. S.A. 1973, c. 33, later R.S.A. 1980, c. L-1, repealed by Employment Standards Act, R.S.A. 1980 (Supp.) c. E-10.1 and by s. 182 of the Labour Relations Act, S.A. 1980, c. 72. 
Accordingly, the Board of Arbitration had the power to determine whether a difference could be the subject of arbitration, and such a decision is "final and binding" on the parties.62 Although in some circumstances the question of arbitrability may undoubtedly be a jurisdictional one, in light of the specific legislation involved in this case, Stevenson J.A. stated as follows: 63

I am of the view that the "enquiry in question" here is whether the alleged grievance is arbitrable. True, the board had jurisdiction to decide other questions, notably whether the grievance, if arbitrable was established and, if established, what remedy ought to be granted, but it undoubtedly had "authority to decide" the question of arbitrability. "Authority to decide" is the definition of jurisdiction given in de Smith's fourth ed. (1980), at p. 110.

The appellants err in subdividing the matter before the board. That is a criticism of jurisdictional arguments referred to by Dickson J. in CUPE, Loc. 963 v. N.B. Liquor Corp. ... Paraphrasing Dickson J., the question of arbitrability is "plainly confided" to the board here. Had the parties posed only a question of whether this allegation was arbitrable, or themselves divided the questions and put this one forward individually[,] it could not be suggested the board lacked jurisdiction to decide that question.

Stevenson, J.A. then distinguished those cases dealing with preliminary or collateral matters, upon which the jurisdiction of a statutory delegate depends: Jacmain ${ }^{64}$ and Jarvis. ${ }^{65} \mathrm{He}$ also distinguished Bell v. Ontario Human Rights Commission, ${ }^{66}$ on the basis that it involved a determination on a question not remitted or confided to the tribunal; 67 and the Anisminic ${ }^{68}$ and Metropolitan Life Insurance ${ }^{69}$ cases. These three cases all involved the "wrong question" being asked by the statutory delegate in such a way as to deprive it of its jurisdiction. By contrast, in the U.N.A. case, the Board of Arbitration clearly had the authority over the "kind of case" involving arbitrability. In short, as Stevenson J.A. said, 70 "the decision on the question of arbitrability is an exercise of jurisdiction rather than a determination of it".

Stevenson J.A. then directed his attention to whether the decision of the Board of Arbitration was "patently unreasonable". After reviewing numerous cases, ${ }^{71}$ going both ways on the matter, he held that they only confirmed that the point subject to determination by the board was an arguable one, and therefore not one in which the court should substitute its opinion.

62. By virtue of s. $138.2(\mathrm{~g})$ of the Act and by virtue of Article 34.05 of the collective agreement.

63. Supran. 60 at p. 9.

64. Supran. 42.

65. Supran. 44.

66. [1971] S.C.R. 756, 18 D.L.R. (3d) 1.

67. That is, whether a "self-contained domestic establishment" was involved.

68. [1969] 2 A.C. 147, [1969] 1 All E.R. 208 (H.L.).

69. [1970] S.C.R. 425, 11 D.L.R. (3d) 336.

70. Supra n. 60 at p. 10.

71. Re Int. Chemical Wkrs. Union. Local 424, Re Horn Co. Ltd. (1954) 4 L.A.C. 1524; R. v. Bd. of Arb., ex parte Stevens (1970) 12 D.L.R. (3d) 284; Re Leamington (1978) 15 L.A.C. (2d) 416; Re Foothills Prov. Gen. Hosp. and Alta. Civic Service Assn. (1974) 7 L.A.C. (2d) 436; Re Retail, Wholesale \& Dept. Store Union and Hershey Chocolate of Canada (1970) 21 L.A.C. 83; Western Co-op Fertilizers Ltd. v. Oil Chemical etc. Int. Union [1971] 3 W.W.R. 628; Zellers (Western) Ltd. v. Retail, Wholesale etc. Union (1973) 40 D.L.R. (3d) 761 (S.C.C.). 
Moir, J.A. concurred in this result, but noted that s. 146 of the Labour $\mathrm{Act}^{72}$ had not previously been construed by the Court of Appeal as a privative clause, and in any event was considerably less strongly worded than the corresponding provisions in the Public Service Employee Relations Act, $1977^{73}$ dealt with by the Supreme Court of Canada in the Olds College case ${ }^{74}$ (discussed below). In particular, Moir J.A. noted that the Court of Appeal had previously interfered for errors of law on the face of the record which were not necessarily "patently unreasonable" in Yellow Cab Ltd. v. Industrial Relations Board, ${ }^{75}$ and Industrial Relations Board v. Stedelbauer Chevrolet Oldsmobile Ltd. ${ }^{76} \mathrm{He}$ criticized the decision of another panel of the Court of Appeal in Suncor 77 which appeared to restrict the Court's ability to review the record under s. 146 of the Labour Act because of the words of a specific clause of the collective agreement in Suncor. Moir J.A. noted that the Court of Appeal was not compelled to reach the decision which it did in Suncor, but now was bound by it, as well as by the subsequent decision of the Supreme Court of Canada in Shalansky. ${ }^{78}$

On a practical level, Moir J.A. was disturbed by the consequence which would result from the application of the "patently unreasonable test" limiting the Court's ability to correct an intra-jurisdictional error of law on the face of the record where no privative clause exists. As His Lordship noted, there are numerous identical collective agreements in existence between the United Nurses and all of the hospitals in the Province. The contractual rights of the Union, its members and the Employer should be identical under all of these contracts, and that matter should be determined once and for all. The Court was well placed to give a uniform construction to the language used in these contracts. ${ }^{79}$ On the other hand, if the same issue could be raised before several different arbitration boards, different results could arise, which could not be made uniform

72. Labour Act, 1973, S.A. 1973, c. 33 [later R.S.A. 1980, c. L-1]; repealed by Employment Standards Act, R.S.A. 1980 (Supp.), c. E-10.1, s. 121], ss. 138 [re-en. 1977, c. 77, s. 11], 146 and by s. 182 of the Labour Relations Act, S.A. 1980 c. 72.

73. S.A. 1977, c. 40 [now R.S.A. 1980, c. P-33].

74. Infra n. 82.

75. (1979) 11 Alta. L.R. (2d) 97,18 A.R. 91 (S.C.C.).

76. [1969] S.C.R. 137, 65 W.W.R. 344, 1 D.L.R. (3d) 81

77. Infra n. 87.

78. Infra n. 106.

79. This argument may be compelling when used to urge the court to issue a prerogative remedy when it has jurisdiction to do so, and not to exercise its discretion to refuse the remedy if the arbitrators' decision is incorrect (even if not patently unreasonable). This reasoning cannot, however, be applied in the U.N.A. case, where a privative clause did exist (at least after the expiration of the 30-day period during which the legislation specifically permitted certiorari to be brought! Query: is it more accurate to characterize this clause as a specific invitation to certiorari within 30-days, but thereafter a privative clause? In effect, is it a time-delayed privative clause? If so, reasoning applicable to a case involving a privative clause cannot properly be used to prevent an application for judicial review which has been brought within the 30-day period during which the statute expressly permits judicial review). 
by the courts unless it could be said that all but one of those interpretations was "patently unreasonable". As His Lordship said:80

The result of this decision is to leave the question to the individual arbitration boards who hear grievances under collective agreements. Whatever these boards decide will be protected unless their decisions are "patently unreasonable" or "clearly wrong". To my mind this is not a desirable result but it must follow from the decision in Suncor and probably Shalansky.

\section{THE "PATENTLY UNREASONABLE" DOCTRINE IN THE ABSENCE OF A PRIVATIVE CLAUSE}

The question then arises as to the applicability of the "patently unreasonable" test to protect intra-jurisdictional errors of law on the face of the record, where no privative clause occurs in the legislation. In principle, certiorari should be available to correct any and all such errors of law. In fact, the courts have recently retreated from such a bold assertion of their jurisdiction, and have tended to restrict the anomalous use of certiorari to correct only certain errors of law. They have done this in two quite distinct ways. First, as Wade notes, ${ }^{81}$ the courts have sometimes held that there is no error of law if the legal conclusion is "within the range of interpretations within which different persons might reasonably reach different conclusions". With respect, there is little to be said for this approach, which simply assumes the problem away. After all, there is only one correct construction of any legal phrase in a particular context, and it is the responsibility of the courts to determine that correct construction. Of course the court may defer to the expertise of a specialized tribunal to arrive at that correct construction but one cannot conclude from such prudence that there can theoretically be more than one correct legal result. This brings us to the second basis upon which the courts might decline to correct an error of law in certain circumstances. Certiorari, after all, is one of the prerogative remedies, all of which are discretionary in nature. It can be argued, therefore, that the Canadian courts have recently decided that they can properly exercise their discretion to refuse certiorari when the intra-jurisdictional error of law is not patently unreasonable. Such an approach does not prevent or restrict the power of the courts to issue certiorari, but rather merely indicates a circumstance where the courts may choose not to do so. At any rate, this rationale is helpful in explaining the recent cases where the courts have adopted the "patently unreasonable" test to refuse to issue certiorari to correct an intra-jurisdictional error of law where no privative clause existed. Let us examine these cases closely.

\section{A. THE OLDS COLLEGE CASE}

The decision of the Supreme Court of Canada in Re Alberta Union of Provincial Employees and Board of Governors of Olds College ${ }^{82}$ is open to two theoretical explanations. On the one hand, the Court may have

80. Supra n. 60 at p. 6.

81. H.W.R. Wade, Administrative Law (4th ed. 1977) 776.

82. (1982) 136 D.L.R. (3d) 1, (1982) 21 Alta. L.R. (2d) 104 (S.C.C.), Martland and Beetz JJ. dissenting. See the comment by Mullan in (1983) 5 Supreme Court Review 24. 
applied the "patently unreasonable" test to prevent judicial review of certain intra-jurisdictional errors of law in the absence of a privative clause. If this reading of the case is correct, the Court has greatly restricted the anomalous use of certiorari to correct errors of law; and it is important to discern the theoretical basis for such a change in the law. On the other hand, it may be possible to construe Olds College as simply breathing life into a "final and binding" clause so as to create an effective privative clause which can only be avoided by an error of law which is so patently unreasonable that it deprives the statutory delegate of its jurisdiction. Such an approach would not alter the function of the "patently unreasonable" test discussed in Part 5 of this paper, but it would seriously change conventional thinking by expanding the ambit of privative clauses. So the Olds College decision must be reckoned with!

The case dealt with the power of the Public Service Employee Relations Board to certify which items were capable of being arbitrated in a dispute concerning the terms of a collective agreement between an employer and a union. Section 9(1) of the $\mathrm{Act}^{83}$ gave the Board extensive powers to decide whether "a matter in dispute is an arbitral item", and stated that the Board's decision was "final and binding". Section 11 of the Act stated that:

11. The Board has exclusive jurisdiction to exercise the powers conferred upon it by or under this Act and to determine all questions of fact or law that arise in any matter before it and the action or decision of the Board thereon is final and conclusive for all purposes, but the Board may, at any time, reconsider any order, notice, directive, declaration, certificate or other decision made by it and vary or revoke it.

[Emphasis added.]

Section 89 of the Act prevented judicial review except by way of an application for certiorari or mandamus filed within 30 days of the impugned decision:

89 (1) No award, proceeding or decision of a tribunal shall be questioned or reviewed in any court, and no order shall be made or process entered or proceedings taken in any court, (whether by way of injunction, declaratory judgment, prohibition, quo warranto or otherwise) to question, review, prohibit or restrain the tribunal in any of his or its proceedings.

(2) Notwithstanding subsection (1), the award, proceeding or decision of a tribunal may be questioned, or reviewed by way of an application for certiorari or mandamus, if an application therefor is filed with the Court not later than $\mathbf{3 0}$ days after the date of the award, proceeding or decision of the tribunal.

Chief Justice Laskin had this to say about the relationship between the "final and binding" clauses and the explicit provision for judicial review: 84

In the face of this explicit provision for review, it is impossible to read it out of this statute or to subordinate it [section 89], to ss. 9 and 11 or even to limit it to questions of jurisdiction in the strict sense, as urged by counsel for the union and counsel for the board. That being said, however, it still remains to consider the scope of review on alleged errors of law, and it is my opinion that the commanding terms of s. 9(1) and especially of s. 11 cast a gloss on the extent to which decisions of the board may be overturned by a court. Certiorari, considered in the light of ss. $9(1)$ and 11 , is a long way from an appeal and is subject to restriction in accordance with a line of decisions of this

83. Public Service Employee Relations Act, S.A. 1977, c. 40, now R.S.A. 1980, c. P-33; paragraph $9(\mathrm{l})(\mathrm{m})$.

84. Supra n. 82 Alta. L.R. at 107. 
court which, to assess them generally, preclude judicial interference with interpretations made by the Board which are not plainly unreasonable. Jurisdictional errors, including want of natural justice, are clearly reviewable and subject to reversal as was conceded by the appellants, but they are not involved here.

It was agreed that none of the alleged legal errors were jurisdictional in nature. ${ }^{85}$ Although a majority of the Alberta Court of Appeal had issued certiorari to correct these intra-jurisdictional errors, Chief Justice Laskin persuaded a majority of the Supreme Court of Canada not to do so for these reasons: ${ }^{86}$

... [I]t is obvious that Prowse J.A. [in the Alberta Court of Appeal] treated the case before him as more akin to an appeal than to one involving a limited right of review. In so doing, he appears to have misapprehended what was involved in McLeod v. Egan [1975] 1 S.C.R. 517, 74 C.L.L.C. 14,220 (Sub. Nom. United Steel Wkrs. v. Galt Metal Indust. Ltd.), 46 D.L.R. (3d) 150, 2 N.R. 443 (subm. Nom. Re MacLeod), and in Re Bradburn and Wentworth Arms Hotel Ltd. [1979] I S.C.R. 846, 79 C.L.L.C. 14,189, 94 D.L.R. (3d) 161. Both these cases, although concerned with grievances under collective agreements, required the arbitration boards (dealing with "rights" arbitrations) to consider applicable public statutes. The interpretation of those statutes did not require so-called curial deference to the views of the arbitration boards.

That, however, is not this case. Here the Public Service Employee Relations Board is operating in its home territory, so to speak. It was concerned with the interpretation and application of provisions confided by its constitutent Act to its exclusive administration, with its decisions stated to have final and conclusive effect. In such circumstances, the proper approach by a reviewing court is not the blunt substitution of judicial opinion for the views of the Board but rather that expressed by Dickson J. in Can. Union of Public Employees, Local 963 v. N.B. Liquor Corp. [1979] 2 S.C.R. 227 at p. 237, 25 N.B.R. (2d) 237, 79 C.L.L.C. 14,209, 97 D.L.R. (3d) 417, 51 A.P.R. 237, 26 N.R. 341 where he formulated the issue of scope of review as follows:

". . . was the Board's interpretation so patently unreasonable that its construction cannot be rationally supported by the relevant legislation and demands intervention by the court upon review?"

I should note that Dickson J. was also dealing with a public service labour relations Act and with the administration of the Act by a board.

Justice Dickson's approach was adopted in Volvo Can. Ltd. v. Int. Union, United Automobile, etc. Wkrs. [1980] I S.C.R. 178, 99 D.L.R. (3d) 193, 27 N.R. 502, in the reasons of Pigeon J. at p. 214, and it is also evident in the reasons of Estey J. speaking for the court in Douglas Aircraft Co. of Can. v. McConnell [1980] 1 S.C.R. 245 at p. 274, 79 C.L.L.C. 14,221 (sub. Nom. Douglas Aircraft Co. v. U.A.W. Loc. 1967) 99 D.L.R. (3d) 385, 23 L.A.C. (2d) 143, 29 N.R. 109.

Needless to say, however the scope of review is limited according to the reach of nearprivative clauses, there is no complete ouster of review, even on errors of law unless a privative clause clearly enjoins interference on this ground: see $\operatorname{Re}$ Ont. L.R.B. and Bradley [1957] O.R. 316, 8 D.L.R. (2d) 65 (C.A.).

His Lordship then examined the arbitrable items in dispute, and concluded that the Board's disposition of them could not be characterized as being "patently unreasonable", so that certiorari would not issue.

\section{B. THE SUNCOR CASE}

The Alberta Court of Appeal adopted this approach with a vengeance in Suncor Inc. v. McMurray Independent Oil Workers, Local 1.87 The Court was required in Suncor to determine whether certiorari was

85. In the narrow sense of the word.

86. Supra n. 82 Alta. L.R. at 109.

87. [1983] 1 W.W.R. 604 (Alta. C.A.). 
available to quash an arbitrator's decision for an intra-jurisdictional ${ }^{88} \mathrm{er}$ ror of law. At the outset, the Court had to determine whether the arbitration was consensual or statutory in nature in order to determine both whether certiorari was available at all and also the test for determining which errors of law could be reviewed by the Court. The parts of the judgment dealing with non-consensual arbitrations are considered below in Part 7 of this paper.

Assuming that the arbitrators were statutory in nature, ${ }^{89}$ Kerans J.A. held that the Court of Appeal was bound by the decision of the Supreme Court of Canada in Olds College to apply the "patently unreasonable" test to limit the availability of certiorari to correct errors of law on the face of the record. His Lordship noted that the wording of the privative clause in section 129 of the Labour Relations Act ${ }^{90}$ was almost identical to the one ${ }^{91}$ from the Public Service Employee Relations Act at issue in Olds College. Section 129 read as follows:

129(1) Subject to subsection (2), no award or proceeding of an arbitrator, arbitration board or other body shall be questioned or reviewed in any court, and no order shall be made or process entered or proceedings taken in any court, whether by way of injunction, declaratory judgment, prohibition, quo warranto or otherwise, to question, review, prohibit or restrain the arbitrator, arbitration board or other body in any of his or its proceedings.

(2) The decision or proceedings of an arbitrator, arbitration board or other body may be questioned, or reviewed by way of an application for certiorari or mandamus, if an application therefor is filed with the court not later than $\mathbf{3 0}$ days after the issuance of the award of the arbitrator, arbitration board or other body.

[Emphasis added.]

Although Kerans J.A. recognized ${ }^{92}$ that this explicit provision for judicial review could not be ignored by the Court of Appeal, he nevertheless held that certiorari would not issue to correct the arbitrator's impugned error of law.

There is one important difference between the Olds College case and the issue in Suncor. In the former, two separate provisions ${ }^{93}$ of the statute itself made the decision of the Public Service Employee Relations Board "final and binding" - and these statutory provisions provided the gloss which permitted Chief Justice Laskin to eviscerate the statutory right to certiorari. In Suncor, however, the legislation only protected decisions of the Labour Relations Board, and not those of arbitrators ap-

88. No suggestion arises in the case that the error was jurisdictional in nature, unlike the submissions in CUPE or Massicotte.

89. This assumption appears to have been correct in light of the almost contemporaneous decision of the Supreme Court of Canada in the Roberval case, supra note 8.

90. R.S.A. 1980, c. L-1.1 (Supp.).

91. Section 89, quoted above in the discussion on Olds College.

92. Supran. 87 at 609.

93. Sections 9 and 11 , quoted above. 
pointed pursuant to the Act. Nevertheless, Kerans J.A. reached down to the collective agreement, which provided that: ${ }^{: 9,95}$

... [t]he decision of the Board of Arbitration shall be final and binding upon the parties and upon all affected employees as set out in The Alberta Labour Act.

His Lordship held that this contractual provision "casts a like gloss on the power of judicial review" similar to the restriction imposed by the Supreme Court of Canada in Olds College. Accordingly, we must now accept that that case of the Supreme Court has overruled the Court of Appeal's decision in Yellow Cab, ${ }^{96}$ as well as the Supreme Court's own decision in Stedelbauer. ${ }^{97}$ As Kerans J.A. said, the law must now be taken to be as follows: ${ }^{98}$

In the result, the combined effect of the decision in N.B. Liquor Corp on the one hand and Olds College on the other is this: the position of the appellant can be no higher than that s. 129(1) prevents review on any standard other than "patent unreasonableness" and that of the respondent no higher than that s. 129(2) (combined with art. 13.09) permits review only by the same standard.

\section{THE U.N.A. CASE}

As noted in the previous part of this paper dealing with cases where privative clauses exist, the Suncor case has been criticized subsequently by Moir J.A. in his dissent in the U.N.A. case. His Lordship noted that all of the statutes in question in Olds College, ${ }^{99}$ Suncor ${ }^{100}$ and U.N.A. ${ }^{101}$ specifically provided for the availability of certiorari. The Court of Appeal had previously used that statutory exception to the privative clause to correct all intra-jurisdictional errors of law, and not just those which were "patently unreasonable": see Yellow Cab ${ }^{102}$ and Stedelbauer. ${ }^{103}$ He objected to the use by Kerans J.A. in Suncor of the "final and binding" clause in the collective agreement to fortify (or "gloss") the terms of the privative clause in the statute, thereby eviscerating the statutory right to certiorari.

94. Article 13.09. Note that the Act does not make the arbitration decision "final and binding", that provision is purely contractual in nature. Thus the phrase "as set out in The Alberta Labour Act" must refer to the provision in the statute which makes a collective agreement binding on employees even though only the employer and the union are privy to it.

95. It is extraordinary that the Court treated a mere contractual "final and binding" clause as though it were equal to the strongest form of privative clause contained in a statute!

96. (1980) 11 Alta. L.R. (2d) 97, 80 C.L.L.C. 14,011, 105 D.L.R. (3d) 467, 18 A.R. 91, overruled by the Supreme Court on other grounds at [1980] 2 S.C.R. 761, 14 Alta. L.R. (2d) 39, 80 C.L.L.C. 14,066, 114 D.L.R. (3d) 427, 24 A.R. 275 where the Court of Appeal had ruled that s. 129(2) permitted the issuance of certiorari to correct any error in law, and not just patently unreasonable.

97. [1969] S.C.R. 137, 65 W.W.R. 344, 1 D.L.R. (3d) 81 . Note, however, that Chief Justice Laskin did not refer to either Yellow Cab or Stedelbauer in Olds College. He did, however, adopt the reasoning of Estey J. in Douglas Aircraft, who specifically adopted the views of Martland $\mathbf{J}$. in Stedelbauer. Accordingly, it is not at all clear that the statement by Kerans J.A. in Suncor is correct with respect to which cases are still good law.

98. Supra n. 87 at 610 .

99. Supran. 82.

100. Supran. 87.

101. Supran. 60.

102. Supran. 96.

103. Supran. 97. 
Although Moir J.A. accepted that the Court of Appeal was bound by Suncor, he noted the practical problems arising from using the "patently unreasonable" test to prevent judicial review of intra-jurisdictional errors. As it happens, there are numerous identical collective agreements in existence between the United Nurses and all of the hospitals in the Province. The contractual rights of the Union, its members and the Employer should be identical under all of these contracts. The Court was well placed to give a uniform construction to the language used in these contracts. On the other hand if the same issue could be raised before several different arbitration boards, different results could arise, which could not be made uniform by the courts unless it could be said that all but one of those interpretations was "patently unreasonable". As His Lordship said: ${ }^{104}$

The result of this decision is to leave the question to the individual arbitration boards who hear grievances under collective agreements. Whatever these boards decide will be protected unless their decisions are "patently unreasonable" or "clearly wrong". To my mind this is not a desirable result but it must follow from the decision in Suncorand probably Shalansky.

This criticism of the "patently unreasonable" test appears to be unanswerable to the extent that the test limits - as a matter of law - the availability of certiorari to correct intra-jurisdictional errors of law where no privative clause exists. On the other hand, if the test is only to be used as a guide for determining the circumstances in which the courts should consider exercising their undoubted discretion to refuse prerogative remedies, the situation may not be as bleak as suggested by Moir J.A. After all, if the latter view is correct, it was open to the court to exercise its discretion to issue certiorari to correct an error of law which was not patently unreasonable, and such a discretionary use of certiorari would clearly be justified to prevent the chaos referred to by Moir J.A.

\section{THE SHALANSKY CASE}

Finally, it is important to note that the "patently unreasonable" test was also applied by both the Saskatchewan Court of Appeal and the Supreme Court of Canada in Shalanskyv. Board of Governors of Regina Pasqua Hospital. ${ }^{105}$ This case undoubtedly dealt with a consensual arbitration, and will be considered at greater length in a later part of this paper. Nevertheless, both Courts specifically refused to review a decision of the arbitrators which was not "patently unreasonable" even if the judges might have preferred a different legal construction of the collective agreement in question. As Chief Justice Laskin said in the Supreme Court's decision: 106

As a matter of interpretation, the Chief Justice [of the Saskatchewan Court of Appeal, Bayda C.J.] was of the view that the board had interpreted the relevant provisions of the collective agreement incorrectly, with the result that there was an error on the face of the award. This conclusion led him to consider whether the award of this consensual board was impeachable. He was of the opinion that the effect of this court's decisions in Bell Canada v. Office \& Professional Employees' Int'l Union, Local I3I (1973), 37

104. Supran. 60 at 6.

105. (1983) 145 D.L.R. (3d) 413 (S.C.C.); affg. 15 Sask. L.R. 253 (C.A.); affg. 10 Sask. L.R. 225 (Q.B.), dismissed an application for judicial review of an arbitration award.

106. Id., at pp. 415-6. 
D.L.R. (3d) 561, [1974] 1 S.C.R. 335; Metropolitan Toronto Police Ass'n et al. v. Metropolitan Toronto Board of Com'rs of Police (1974), 45 D.L.R. (3d) 548, [1975] 1 S.C.R. 630, 2 N.R. 95, and Volvo Canada Ltd. v. Int'l Union, United Automabile, Aerospace \& Agricultural Implement Workers of America, Local 720 (1979), 99 D.L.R. (3d) 193, [1980] 1 S.C.R. 178, 33 N.S.R. (2d) 22, was that the proper issue was not whether the submission to arbitration was of a specific quetion of law or a general question in the course of which questions of law arose but there was rather a third category, namely, whether the issue submitted to arbitration constituted a grievance in the course of whose determination questions of the construction of the collective agreement arose. In his view, if the issue submitted to arbitration was in this category, an error by the board in its interpretation is not reviewable unless the interpretation is outrageous or patently unjustifiable (words used in the dissent in the Bell Canada case) or patently unreasonable (to use the words of Pigeon $\mathrm{J}$. in the Volvo case).

1 agree with Chief Justice Bayda that there is no significant difference in the meaning of the aforementioned three terms. Indeed, it would be my view that, apart from a question of emphasis, the test of unreasonableness or test of clearly wrong is also not different. Bayda C.J.S. himself concluded that the board was presented with two reasonable constructions and hence was entitled to choose the one it did rather than the one preferred by the Chief Justice. In the result, he dismissed the appeal.

In my opinion, this is the correct approach. Once it is accepted that there are two reasonable interpretations, the suggestion of a reviewable error of law in consensual arbitration disappears. There is no need to construct a third category, namely, reference to an arbitrator involving construction of a collective agreement. The principle on which this so-called third category is founded is the very principle applicable in all consensual arbitration cases. The decision of the arbitrator can be set aside only if it involves an interpretation which the words of the agreement could not reasonably bear.

\section{E. SUMMARY}

The Olds College, ${ }^{107}$ Suncor, ${ }^{108}$ U.N.A. ${ }^{109}$ and Shalansky ${ }^{110}$ cases all demonstrate that the courts have adopted the "patently unreasonable" test to restrict the availability of certiorari in cases where no privative clause exists. These cases, therefore, are qualitatively different from those involving a privative clause. In the latter category, it is necessary to find that the error of law is "patently unreasonable" in order to characterize it as jurisdictional in nature, and thereby not protected by the privative clause. In other words, the "patently unreasonable" test is used as a sword to defeat the operation of a privative clause. Very oddly, the very same words have been used for precisely the opposite purpose by the courts in the Olds College line of cases. To protect intra-jurisdictional errors of law where there is no privative clause effectively converts the "patently unreasonable" test into a shield, not a sword. To the extent that this novel use of the test in fact limits the availability of certiorari as a matter of law and not as a matter of discretion, the test really amounts to a judicially-constructed privative clause!

Before trying to sort out these greater issues of policy, it may be useful to consider the parallel development of the common law action to quash and remit the decision of a consensual arbitrator, which has not always reflected either the availability or the test for certiorari to correct intrajurisdictional errors of law on the face of the record.

107. Supran. 82.

108. Supra n. 87.

109. Supran. 60.

110. Supran. 105. 


\title{
VIII. THE COMMON LAW ACTION TO QUASH AND REMIT THE DECISION OF A CONSENSUAL ARBITRATOR
}

\section{A. WHAT ARE CONSENSUAL ARBITRATIONS?}

It is important to note that the superior courts have a separate general superintending and reforming power with respect to all arbitrations, even if they are not statutory in nature, so that certain errors committed by arbitrators are susceptible to judicial review, even if not by way of certiorari. In Association of Radio and Television Employees of Canada (CUPE-CLC) and the Canadian Broadcasting Corporation, ${ }^{111}$ the Supreme Court of Canada (per Laskin J.) dealt with this point as follows:

\begin{abstract}
However, the Court in the Howe Sound case did not go on to say that the fact that certiorari would not lie did not mean that review under the common law or under a general arbitration statute was precluded.

This latter point was re-stated and expanded by this Court in Port Arthur Ship Building Co. v. Arthurs, [1969] S.C.R. 85, at pp. 94-95. The effect of what was said there is to deny homage to technicality, and to make it clear that where the proceedings to review a decision of a board of arbitration are made by way of a motion to quash or to set aside the award, dispensing with the issue of a writ of certiorari, it matters not whether the board of arbitration is or is not a statutory tribunal in any strict sense. I agree with this view of the issue and would add that it would be equally resolved by the bringing of an action for a declaration. Having regard to the form of the proceedings in the present case, it is unnecessary to consider whether the board of arbitration was a statutory tribunal in the Rivando sense or was a non-statutory tribunal in the Howe Sound sense. In either case, there was jurisdiction in the Manitoba Court of Queen's Bench.
\end{abstract}

Other authorities on the inherent jurisdiction of the superior courts to review and reform awards of consensual arbitration boards include: $R e$ Oil Chemical \& Atomic Workers' International Union, Local 9-14 and Polymer Corporation; ${ }^{112}$ Athabasca Realty Co. Ltd. v. Merenick; ${ }^{113}$ Arbitration Act, ${ }^{114}$ and the decision of the Alberta Court of Appeal in Suncor ${ }^{115}$ (where only certiorari was sought, but the Court was prepared if necessary to grant another remedy to review the arbitrator's award if it was non-statutory in nature). The technical distinction between statutory and consensual arbitrations should become much less important - at least in the labour field - in light of the Supreme Court's decision in Roberval ${ }^{116}$ to the effect that the choice of arbitration in fact makes that arbitration board a statutory one, even though the parties under the statute could have chosen some other method for resolving their dispute. Nevertheless, certiorari is only available against statutory bodies, and the common law action to quash and remit a decision in only available against a consensual arbitrator: Racecourse Betting Control Board v. Secretary of Air. ${ }^{117}$ The two remedies are mutually exclusive, therefore, and some care is necessary in determining which one applies to the particular case at hand.

111. 73 C.L.L.C. para. 14,189, [1975] 1 S.C.R. 118, a case where arbitration was the only method for settling the differences. [Emphasis added.]

112. [1966] 1 O.R. 774, 55 D.L.R. (2d) 198 at p. 208 (H.C.).

113. [1982] Alta. D. 1293-01 (Q.B.).

114. R.S.A. 1980 , c. A-43.

115. Supran. 87.

116. Supran. 8.

117. [1943] Ch. 198. 
B. IS THE TEST FOR CERTIORARI FOR ERRORS OF LAW THE SAME AS THAT FOR THE COMMON LAW ACTION TO QUASH AND REMIT?

In any event, it may be dangerous to assume that the ambit of the court's power to review the decision of a statutory arbitration board by certiorari is identical to the ambit of its inherent power to review awards of consensual arbitration boards. Chouinard J. referred to this distinction in Roberval ${ }^{118}$ when noting the distinction between the ambit of a direct action in nullity under Article 33 of the Quebec Code of Civil Procedure (which closely resembles a declaration or a declaratory order in Alberta), and the grounds for the availability of evocation under Article 846 of the Quebec Code of Civil Procedure (which is a statutory amalgamation of the prerogative remedies of prohibition and certiorari, both of which continue their separate existences in Alberta.) ${ }^{119}$

First, both the Quebec action in nullity and the common law declaration are only available once the arbitrator has rendered his decision, whereas prohibition (ie., an anticipatory certiorari) may be available to prevent an error of law being made prior to that point in time.

Secondly, the Quebec action in nullity only applies to cases of excess of jurisdiction or to an injustice amounting to fraud (which probably is a particular example of an action taking the delegate outside of his jurisdiction), and cannot be used to correct an error of law within the delegate's jurisdiction. Similar restrictions apply to the availability of a declaration under the common law ${ }^{120}$ where the error lies within the delegate's jurisdiction, because such a decision must be quashed. A declaration quashes nothing; this can only be done by an order of certiorari.

Thirdly, the Arbitration Act ${ }^{121}$ of Alberta specifically prescribes the standard of judicial review of a decision of a non-statutory arbitrator in terms of "misconduct". Historically, the courts construed "misconduct" to mean corruption or other undue means, which did not include errors of law by the arbitrator. This approach was changed, however, in Kent v. Elstob, 122 and "misconduct" was expanded to include all errors of the law on the face of the record. The Alberta Court of Appeal recently restated this doctrine in R.O.M. Construction Ltd. v. Electric Power Equipment Ltd. ${ }^{123}$ which holds that review of consensual arbitrations is available for any error of law on the face of the record, and is not restricted only to those errors which are patently unreasonable. Unfortunately, the clarity of this rule has been muddied by obiter dicta in the subsequent decision of the Alberta Court of Appeal in the Suncor

118. Supran. 8.

119. See also the decision in Vachon v. Attorney-General of the Province of Quebec [1979] 1 S.C.R. 555; and City of Chicoutimi v. Seminary of Chicoutimi [1973] S.C.R. 681; affg. [1970] B.R. 413.

120. See Punton (No. 1) supra, n. 3.

121. Supran. 114.

122. (1802) East 18, regretted but not reversed in Hodginson v. Fernie(1857) 3 C.B.N.S. 189.

123. [1981] 4 W.W.R. 97, 121 D.L.R. (3d) 753, 30 A.R. 600 (Alta. C.A.), leave to appeal to S.C.C. refused at 121 D.L.R. (3d) $753 n, 29$ A.R. 539. 
case $^{124}$ where Kerans J.A. indicates that the standard of review is the same for consensual or statutory arbitrations: namely, whether the arbitrator has committed an error of law which is patently unreasonable, and not whether he has committed an error of law pure and simple. Regrettably, Kerans J.A. simply asserts in Suncor that consensual arbitrations are subject to the patently unreasonableness test, relying on the rationale expressed by Dickson J. in C.U.P.E. Local 963 v. N.B. Liquor Corporation, ${ }^{125}$ as follows:

\begin{abstract}
It is contended, however, that the interpretation placed upon [the section in dispute] was so patently unreasonable that the Board, although possessing "jurisdiction in the narrow sense of authority to enter upon an inquiry", in the course of that inquiry did "something which takes the exercise of its powers outside the protection of the privative or preclusive clause". . . . Put another way, was the Board's interpretation so patently unreasonable that its construction cannot be rationally supported by the relevant legislation and demands intervention by the court upon review?
\end{abstract}

However, it is important to note that the CUPE case undoubtedly dealt with a statutory power, so it is difficult to understand why Kerans J.A. relied upon this quotation to assert that the "patently unreasonable" test applies to determine the standard of review to be applied to consensual arbitrators under the court's inherent jurisdiction or under the Arbitration Act's reference to "misconduct". Nevertheless, this new approach has been recently confirmed by the Supreme Court of Canada in Shalansky v. Board of Governors of Regina Pasqua Hospital, ${ }^{126}$ which clearly dealt with a consensual arbitration. On behalf of a unanimous five-member panel, Laskin C.J.C. specifically stated that: ${ }^{127}$

... [o]nce it is accepted that there are two reasonable interpretations, the suggestion of a reviewable error of law in consensual arbitration disappears. . . The decision of the arbitrator can only be set aside if it involves an interpretation which the words of the agreement could not reasonably bear.

\title{
C. SUMMARY
}

In summary, then, the courts have a general power to issue certiorari to review certain errors of law made by a statutory delegate in the course of the exercise of his jurisdiction. The error must appear on the face of the record. And recent jurisprudence indicates that the courts will only review such errors if they are patently unreasonable, patently unjustifiable, outrageous, or clearly wrong. ${ }^{128}$ Although certiorari is not available against consensual arbitrations, ${ }^{129}$ the definition of what constitutes a statutory arbitration has been extended considerably by the Roberval case. ${ }^{130}$ Further, the courts have a parallel common law power to quash and remit the decision of the consensual arbitrator for miscon-

124. Supra n. 87.

125. [1979] 2 S.C.R. 227 at 237, 79 C.L.L.C. 14,209, 97 D.L.R. (3d) 417, 25 N.B.R. (2d) 237.

126. (1983) 145 D.L.R. 413 (S.C.C.).

127. Id. at p. 416.

128. Id. at pp. 415-416.

129. Unless of course legislation specifically makes certiorari available in such a non-statutory context. The Labour Act may do precisely this by specifically making certiorari available against the decision of an arbitration tribunal, which (at least prior to Roberval and Suncor) might be characterized as being consensual in nature.

130. Supran. 8. 
duct, which has been defined to include committing an error of law on the face of the arbitration award. The Supreme Court of Canada in Shalansky ${ }^{131}$ has recently narrowed this supervisory power to correct only patently unreasonable errors of law made by consensual arbitrators. Although the legal reasoning process involved in getting to this result may be perplexing, the end result makes the rules coincide for judicial review of both statutory delegates and consensual arbitrations, and reflects a certain degree of judicial restraint in reviewing the decisions of delegates to whom either the legislators or adverse parties have remitted the power to make decisions. In principle, this operating rule should apply to judicial review of all discretionary powers, and not just to labour matters which are statutory or consensual in nature. After all, judicial review of labour matters is merely a particular application of the general principles of Administrative Law!

\section{DOES THE "PATENTLY UNREASONABLE” TEST APPLY TO SHIELD JURISDICTIONAL ERRORS?}

It is important to recall again that the "patently unreasonable" test performs two quite distinct functions. First, the test is used as a sword to avoid the effect of a privative clause by characterizing any "patently unreasonable" error of law as one which goes to the jurisdiction of the statutory delegate. Secondly, the test has recently been expanded by the Olds College case to act as a shield to prevent judicial review of intrajurisdictional errors of law which are not "patently unreasonable", even where no privative clause is involved. The interesting question then arises whether this form of curial deference will also be applied to protect jurisdictional matters which have not been determined in a "patently unreasonable" manner by the statutory delegate? In principle, the answer to this question should be a resounding "no" for the following reasons, although some contrary dicta do exist.

First, no statutory delegate can lawfully extend the jurisdiction delegated to him by the legislative branch. This is the doctrine of ultra vires: the superior courts have made this rule effective by judicial review. To permit a delegate to expand his jurisdiction by committing an error of law (or jurisdictional fact) would subvert this high constitutional principle. The reasonableness of such an error of law is really irrelevant to the jurisdictional question involved. Indeed, Wachowich J. applied this principle in $R$. v. Alberta Labour Relations Board, ${ }^{132}$ where he specifically held that the "patently unreasonable" test does not apply to an error on a jurisdictional matter. ${ }^{133}$

131. Supran. 105.

132. (1983) 27 Alta. L.R. (2d) 338 at p. 343.

133. The error dealt with a failure to consider relevant evidence, which His Lordship held constituted a jurisdictional matter. (But not "in the narrow sense" so often referred to by Dickson J! See Service Employees Int. Union v. Nipawin Dist. Staff Nurses Assn. [1975] 1 S.C.R. 382, [1974] 1 W.W.R. 653, 41 D.L.R. (3d) 6 at 11-12, and the cases cited therein.) Query whether Wachowich J. correctly characterized this alleged error as being "jurisdictional" in nature. Interestingly, he justified his decision on the alternative basis that the alleged error of ignoring evidence was "patently unreasonable" in any event! 
Secondly, a close reading of the cases referred to in this paper indicates that the courts have very definitely maintained the distinction between jurisdictional and intra-jurisdictional errors - although putting the distinction into practice may be difficult! Thus, in CUPE Dickson J. noted that there was no preliminary or collateral question involved which could affect the Board's jurisdiction. He characterized the alleged legal error as being intra-jurisdictional in nature, and indicated that the courts should generally do so in cases of doubt: ${ }^{134}$

\footnotetext{
The question of what is and is not jurisdictional is often very difficult to determine. The Courts, in my view, should not be alert to brand as jurisdictional, and therefore subject to broader curial review, that which may be doubtfully so.
}

This approach recognizes both the possibility of jurisdictional errors and the wider ambit of judicial review to correct such errors. It also allows the courts to distinguish the Jacmain, ${ }^{135}$ Parkhill Bedding, ${ }^{136}$ Jarvis, ${ }^{137}$ Anisminic, ${ }^{138}$ Metropolitan Life Insurance ${ }^{139}$ and Bell ${ }^{140}$ cases on the basis that they deal with jurisdictional errors. Chief Justice Laskin recognized the concept of jurisdictional errors in Massicotte, ${ }^{141}$ as did Stevenson J.A. in United Nurses ${ }^{142}$ - although jurisdictional errors were held not to be involved in either case. Accordingly, one must conclude that judicial review for jurisdictional error has not been affected by the recent use of the "patently unreasonable" test to shield certain intrajurisdictional errors from judicial review.

Thirdly, the very use of the "patently unreasonable" test as a sword to permit judicial review in the face of a privative clause must demonstrate the continued importance of jurisdictional matters. After all, judicial review can in theory only occur where there is a privative clause because a jurisdictional error is involved. The use of the "patently unreasonable" doctrine in this circumstance in effect denotes that what might otherwise have been an intra-jurisdictional error is so objectionable that it has deprived the statutory delegate of his jurisdiction, and hence of the protection of the privative clause.

Fourthly, it is important to remember that certain matters which otherwise would be jurisdictional in nature may by legislation be placed within the delegate's jurisdiction. Thus, in the U.N.A. case, the question whether an item was arbitrable was specifically stated by the legislation to lie within the jurisdiction of the arbitration board, even though in other cases such an issue would be preliminary or collateral to the arbitrator's jurisdiction. The application of the "patently unreasonable" test by the court to prevent judicial review in the U.N.A. case, therefore, must not be misread to suggest that that test applies to jurisdictional matters too.

134. (1979) 97 D.L.R. (3d) 417 (S.C.C.), at p. 422.

135. Supran. 42.

136. Supran. 43.

137. Supran. 44

138. Supran. 68.

139. Supran. 69.

140. Supra n. 66.

141. Supra n. 49.

142. Supran. 60. 
Similarly, some jurisdictional matters are specifically made elastic or subjective by the legislation involved. Thus, in Liversidgev. Anderson, ${ }^{143}$ the Home Secretary was given power to intern enemy aliens whom he had reason to believe were dangerous to the security of the United Kingdom. The majority of the House of Lords held that the powers granted to the Home Secretary were so subjective in nature that it would be impossible for their exercise to be reviewed by the courts. This does not mean that no jurisdictional question could ever be raised concerning any particular exercise of the Home Secretary's internment powers say, for example, if malice, bad faith or an improper purpose could be demonstrated.

In theory, therefore, the "patently unreasonable" test should have no application to shield any jurisdictional matters from judicial review.

On the other hand, certain conflicting dicta indicate that the courts may apply the "patently unreasonable" test even to jurisdictional questions, contrary to all theory. In his dissenting opinion in Jacmain, ${ }^{144}$ Dickson J. ${ }^{145}$ suggests that judicial review should not issue even on a jurisdictional matter - whether of fact or law - unless the delegate's decision on that matter lacks a rational basis or is manifestly in error in short, is "patently unreasonable". In Jacmain, the issue was whether a probationary employee was dismissed for disciplinary reasons or rejected for inadequacy. In the former case, an appeal lay to an arbitration board, but which had no jurisdiction in the latter case. The board heard evidence on the nature of the dismissal, and took jurisdiction because it held discipline in fact was involved. The majority of the Supreme Court held that the board erred in this conclusion. Laskin, Dickson and Pigeon JJ. dissented, and would have exercised curial deference to the findings of the Board with respect to which its jurisdiction depended. This approach no doubt explains Dickson J.'s comments in the CUPE case ${ }^{146}$ urging the courts to characterize alleged errors as being intra-jurisdictional in nature whenever possible, and not jurisdictional. At any rate, it is important to note that the prerogative remedies are discretionary in nature, and may be refused by the courts even when a jurisdictional point is involved. ${ }^{147}$

143. [1942] A.C. 206 (H.L.). Note Lord Atkins's vehement dissent, which would have construed the enabling legislation in objective terms not subjective ones. Such an approach would make judicial review more easily available because the court could determine whether those objective factors existed (i.e., whether there in fact were reasonable grounds, instead of whether the Minister believed there were).

144. Supran. 42.

145. On behalf of himself, Laskin C.J.C. and Spence J.

146. Supran. 37.

147. Stevenson J.A. makes a similar comment in the UNA case, supra n. 60, at p. 10:

A tribunal necessarily has the authority to decide whether a.matter before it comes within its jurisdiction. What the courts must decide is what limitations there are on that authority. Even if we are to accept the appellant's argument that the matter before the board was the question of just cause, and that arbitrability is preliminary or collateral, nonetheless the statute and agreement expressly commit this question to arbitrators whose decision is final and binding. This is contrasted with cases where the tribunal may only act if certain facts exist, a distinction noted by Lord Esher M.R. in R. v. Income Tax Special Purpose Commr. (1888), 21 Q.B.D. 313 at 319 (C.A.), quoted by Wade, Administrative Law, 4th ed. (1977), at p. 244. Even in such cases curial deference may require restraint if it is found that a preliminary fact issue was intended to be resolved by a tribunal. [Emphasis added.]

It is suggested that this dictum must be very carefully limited to the type of hypothetical statutory provisions referred to by Stevenson J.A. at the end of the quotation. 


\section{RATIONALES FOR USING THE "PATENTLY UNREASONABLE" TEST AS A GUIDE FOR EXERCISING DISCRETION TO REFUSE JUDICIAL REVIEW OF INTRA-JURISDICTIONAL ERRORS}

As indicated earlier, some rationale must be found for using the "patently unreasonable" test to restrict judicial review of intrajurisdictional errors where no privative clause exists, as was done in the Olds College, ${ }^{148}$ Suncor, ${ }^{149}$ U.N.A. ${ }^{150}$ and Shalansky ${ }^{151}$ cases. It has already been suggested that these cases cannot theoretically be read to prevent certiorari from issuing - as a matter of law - to correct such an error, even if it is not patently unreasonable. On the other hand, it has also been suggested that the "patently unreasonable" test may be useful in helping the courts to decide whether to exercise their discretion to refuse judicial review. Let us, therefore, now examine the circumstances to which the courts have hitherto referred to justify such a discretionary refusal of a prerogative remedy, as well as the policy reasons referred to by them in adopting the "patently unreasonable" test to refuse certiorari in the absence of a privative clause.

Professor de Smith recognized ${ }^{152}$ only three cases in which the courts exercised their discretion to refuse prerogative remedies:

(i) where there is an appeal which provides a more ef fective remedy;

(ii) where the applicant's conduct has disentitled him to relief; and

(iii) where it would be pointless to issue the remedy.

The "patently unreasonable" test does not fit in any of these three categories. To be fair, the courts have not attempted to relate the "patently unreasonable" test to any of these categories, and have very seldom even acknowledged that using this test involves their discretion to refuse judicial review. Let us see what their Lordships have said.

Kerans J.A. rationalized the restricted availability of certiorari to correct errors of law in light of the summary nature and perceived speed of the arbitration process. His comments deserve quotation at length to see whether they really bear out the need to restrict certiorari in this manner: 153

The object of the Labour Relations Act is to require some form of summary resolution of disputes which arise during the currency of a collective agreement. As Pigeon J. said in Volvo Can. Ltd. v. Int. Union, United Auto. etc., Wkrs., [1980] 1 S.C.R. 178, 99 D.L.R. (3d) 193 at 222, 27 N.R. 502:

". . . the arbitration is not meant to be an additional step before the matter goes before the Courts, the decision is meant to be final."

In my view, there is much to be said for judicial restraint in the face of summary disposition of grievances under collective agreements, whether this disposition is imposed or voluntary. Legislators impose summary process for the same reasons that individuals agree on it: those who choose arbitration in substitution for traditional pro-

148. Supra n. 82.

149. Supra n. 87.

150. Supra n. 60.

151. Supran. 105.

152. J.M. Evans, de Smith's Judicial Review of Administrative Action (4th ed. 1980) at pp. $422-$ 428. See D.P. Jones, "Discretionary Refusal of Judicial Review in Administrative Law" (1981) 19 Alta. L. Rev. 483.

153. Supra n. 87 at pp. 610-611 in W.W.R. (emphasis added). 
cess perceive themselves as having a greater interest in quickness and cheapness than in "correctness". They select a summary process in the hope that it will be quick and cheap. That this hope is often in vain is not material; nor is it material that this hope is sometimes founded in a simplified procedure and sometimes in the expertise of the substitute tribunal; nor is it material that they may have misjudged the capacity of traditional process fairly to balance the three criteria. I distinguish summary process from specialized process, where the trier has special knowledge and the hope is that his expertise will produce a result more correct than if considered in the traditional process.

Of course, the advantage of summary or special disposition never outweighs the disadvantage of a decision which provokes outrage. So all such process is subject at least to minimal review.

The courts sometimes strain at the leash fashioned by a privative clause. Perhaps this is because they do not agree with the legislature that, in the circumstances of the case, the advantages of summary process outweight the disadvantages. Be that as it may, the process at least of arbitration of grievances under collective agreements is, in this day, one best left largely alone by the courts.

That this consideration justifies a standard of review so narrow as the "patent unreasonableness" test is a decision which, in my view, has been made for us by the Supreme Court of Canada in Olds College. And it follows that the standard of review is that test, whether the arbitration here can be classified as consensual or compulsory.

\section{Kerans J.A. therefore justifies the discretionary ${ }^{154}$ refusal of certiorari because of the compelling need for speedy decisions, even if incorrect. $\mathrm{He}$ notes that this is not the same as exercising curial restraint because of the specialized nature of the statutory delegate, which Dickson J. relied on in CUPE: ${ }^{155}$}

[The privative clause] ... constitutes a clear statutory direction on the part of the Legislature that public sector labour matters be promptly and finally decided by the Board. Privative clauses of this type are typically found in labour relations legislation. The rationale for protection of a labour board's decisions within jurisdiction is straightforward and compelling. The labour board is a specialized tribunal which administers a comprehensive statute regulating labour relations. In the administration of that regime, a board is called upon not only to find facts and decide questions of law, but also to exercise its understanding of the body of jurisprudence that has developed around the collective bargaining system, as understood in Canada, and its labour relations sense acquired from accumulated experience in the area.

The usual reasons for judicial restraint upon review of labour board decisions are not only reinforced in a case such as the one at bar. Not only has the Legislature confided certain decisions to the administrative board, but to a separate and distinct Public Service Labour Relations Board. That Board is given broad powers - broader than those typically vested in a labour board - to supervise and administer the novel system of collective bargaining created by the Public Service Labour Relations Act. The Act calls for a delicate balance between the need to maintain public services, and the need to maintain collective bargaining. Considerable sensitivity and unique expertise on the part of the Board members is all the more required if the twin purposes of the legislation are to be met. Nowhere is the application of those skills more evident than in the supervision of a lawful strike by public service employees under the Act. Although the New Brunswick Act is patterned closely upon the federal Public Service Staff Relations Act, R.S.C. 1970 , c. P-35, s. $102(3)$ is not found in the federal legislation nor, in fact, in any other public sector labour legislation in Canada. The interpretation of s. 102(3) would seem to lie logically at the heart of the specialized jurisdiction confided to the Board. In that case, not only would the Board not be required to be "correct" in its interpretation, but one would think that the Board was entitled to err and any such error would be protected from review by the privative clause in s. 101: see Farrell v. Workmen's Compensation Board and A.-G B.C. (1961), 31 D.L.R. 177, [1962] S.C.R. 48, 37 W.W.R. 39.

In my view, that would be sufficient to dispose of this appeal.

154. Although he nowhere speaks in terms of discretion.

155. Supran. 37 at pp. 423-424. 
And this passage was quoted with approval by Laskin C.J.C. in Massicotte, ${ }^{156}$ and again referred to in his judgment in Olds College. ${ }^{157}$

Accordingly, it appears that one must add the following two reasons to the list of justifications for refusing judicial review:

(iv) where the specialized knowledge of the statutory delegate indicates the courts should not interfere;

and (v) where the advantages of the summary and speedy nature of the administrative process outweighs the public interest in having the law correctly applied in all cases.

In any event, it is important to remember that the discretion to refuse prerogative remedies is precisely that: discretionary. Thus, none of these considerations should bind the courts to refuse judicial review where other considerations require it - such as those referred to by Moir J.A. in the UNA case. ${ }^{158}$ Finally, it is important to remember that not all remedies for illegal administrative action are discretionary in nature. ${ }^{159}$

\section{CONCLUSION: CAN AN INTRA-JURISDICTIONAL ERROR OF LAW STILL EXIST UNDER THE "PATENTLY UNREASONABLE" TEST?}

It will be recalled that the purpose of this paper has been to examine the anomalous availability of certiorari to correct intra-jurisdictional errors of law on the face of the record. To do this, it was necessary to examine (i) the distinction between errors which deprive a statutory delegate of his jurisdiction; (ii) the general limitations on the availability of certiorari as a remedy; (iii) the extent of the "record"; (iv) the distinction between errors of "law" and other kinds of errors;" ${ }^{160}(v)$ the use of

156. Supran. 49 at p. 394.

157. Supra n. 82 at p. 110 (Alta. L.R.).

158. Supra n. 60. A further circumstance in which the court may exercise its jurisdiction to refuse a prerogative remedy may arise when the error would not affect the result: see the Canadian Kellog case [1976] 2 W.W.R. 67 (Alta. S.C.T.D.).

159. E.g., the right to damages is not discretionary (although the amount thereof may be). See the discussion of the consequences of this point in D.P. Jones, "Discretionary Refusal of Judicial Review in Administrative Law" (1981) 19 Alta. L. Rev. 483.

160. Consider Dickson J.'s comments on this point in the Jacmain case, supra n. 42 at p. 12 (D.L.R.):

It seems to me that, in the present case, nothing turns on the distinction between fact and law; it is immaterial whether the question is classified as one of fact, or law, or a mixed question of fact and law. The key distinction is between jurisdictional questions (whether of fact, or law, or both) and non-jurisdictional questions. An answer beyond the permissible latitudes to a jurisdictional question causes the tribunal either to act beyond its jurisdiction (if it decided to consider the merits when it has no authority to do so), or to refuse to exercise its jurisdiction (if it decides that it does not have authority to consider the merits when actually it does have such authority). Thus, an error is reviewable under s. 28(1) of the Federal Court Act. Only if a question is non-jurisdictional does the characterization of it as one of fact, or law, become material. If it is a question of law, s. 28(1)(b) applies and any error is subject to review. It it is a question of fact, s. 28(1)(c) applies and an error is reviewable only if it is made in a perverse or capricious manner, or without regard for the material before the tribunal.

The crucial question, therefore, to be determined may be simply stated - was the adjudicator wrong? Did his decision with respect to jurisdiction fall outside tolerable parameters? 
the "patently unreasonable" test to identify jurisdictional errors, in particular to avoid the effect of a privative clause; (vi) the new use of the "patently unreasonable" test to determine whether the court should exercise its discretion to refuse certiorari where there is no privative clause to protect an intra-jurisdictional error of law; (vii) the common law action to quash and remit a decision of a consensual arbitrator which is "patently unreasonable"; (viii) whether the "patently unreasonable" test should apply to determine whether a statutory delegate has committed an error on a matter which is undoubtedly jurisdictional in nature; and (ix) the rationales used by the courts in adopting the "patently unreasonable" test for curial deference in correcting decisions of statutory delegates. The law on this subject is complicated, and has moved very rapidly in the past few years.

In one respect, the "patently unreasonable" test is not new at all. The courts have long used the test to identify a jurisdictional error, and thereby avoid the effect of a privative clause. The recent cases on this point - Volvo, ${ }^{161}$ CUPE, ${ }^{162}$ Massicotte, ${ }^{163}$ one interpretation of Olds College ${ }^{164}$ - are therefore only recent applications of previously wellrecognized law.

On the other hand, the courts have clearly developed new law in using the "patently unreasonable" test to shield a non-jurisdictional error in the absence of a privative clause. Thus, a second interpretation of Olds College, ${ }^{165}$ Suncor ${ }^{166}$ and $U N A{ }^{167}$ represent new law. Coupled with the Roberval ${ }^{168}$ decision extending the category of what constitutes a staturory decision, as well as the Shalansky ${ }^{169}$ case applying the "patently unreasonable" test to non-statutory arbitrations, the new use of the test may well have become universal. As Kerans J.A. said in Suncor. ${ }^{170}$

In the result, the combined effect of the decision in N.B. Liquor Corp. on the one hand and Olds College on the other is this: the position of the appellant can be no higher than that s. 129(1) prevents review on any standard other than "patent unreasonableness" and that of the respondent no higher than that S. 129(2) (combined with art. 13.09) permits review only by the same standard.

The effect of this new use of the "patently unreasonable" test may well be to obliterate the notion of an error of law on the face of the record within jurisdiction. On the one hand, the error is patently unreasonable, it clearly constitutes a jurisdictional matter. On the other hand, if the courts will not review an intra-jurisdictional error which is not patently unreasonable, certiorari will never issue for an error within jurisdiction. In short, if the only errors which can be reviewed are those which are patently unreasonable, they must be jurisdictional in nature! What a

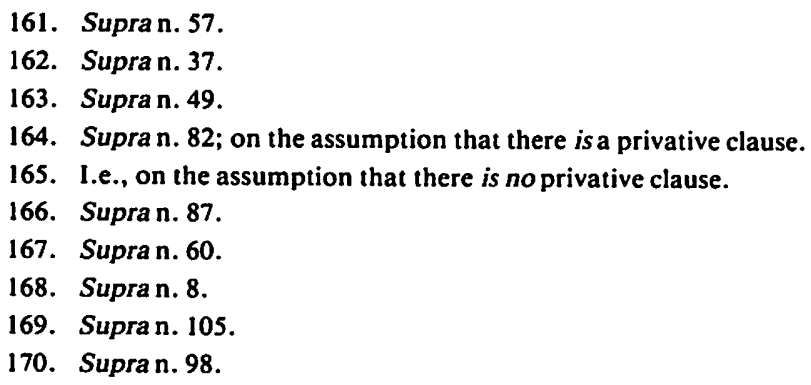


strange comparison to Lord Denning's statement of the law in the Shaw case!

The only possible way to reconcile the new use of the "patently unreasonable" test as a shield with Lord Denning's statement of the law in Shaw is to recognize that the courts are using the test as a guideline to determine when to exercise their discretion to refuse a prerogative remedy when a case for judicial review has otherwise been established. As Moir $\mathrm{J} . \mathrm{A}$. implies in $U N A,{ }^{171}$ such curial deference should not be absolute, but should yield in the face of more compelling reasons for judicial review to correct an intra-jurisdictional error of law.

In principle, the new use of the "patently unreasonable" test should apply as a shield for all statutory delegates, and not just in the labour context. Certainly, the rationales for curial deference in the recent cases apply throughout Administrative Law.

Finally, it is important to remember that the "patently unreasonable" test should have no application to questions of jurisdiction in the narrow sense of the word. No statutory delegate should be allowed to expand his jurisdiction beyond that granted by legislation. In theory, curial deference has no place in this context. 